\title{
VIDEO ASSISTED QUANTUM LEARNING DESIGN TO IMPROVE PSYCHOMOTORIC LEARNING ACHIEVEMENT
}

\author{
Wilfridus Muga \\ STKIP Citra Bakti, Nusa Tenggara Timur, Indonesia \\ Email:faneza_27m@yahoo.co.id
}

\begin{abstract}
This paper aims at investigating how video-assisted quantum learning design improves the learning achievement on psychomotor aspect. This paper is constructed of review of related literature, deep investigation on journal articles and related empirical studies. Quantum teaching is an instructional design which integrates arts and feasible goals in all subjects. Quantum teaching is a shift in learning condition where interaction and interrelationship are used to maximize learning condition. In its relation to improve learning desire, a motivated and interesting media is highly needed. Video as media is integrated in the quantum strategy to maximize learning achievement particularly on the psychomotor aspect. Video contains audio, visual, and messages in form of concepts, principle, procedure, theories, application to help learners understanding a particular topic. These forms of messages are all delivered through the audio and visualisation simultaneously.
\end{abstract}

Keywords: quantum, video as media, psychomotor

\section{Introduction}

Innovative model is the basic of learning contains the steps which demands domination on the learner's activity. Teacher as the learning facilitator always motivates and gives an inquiry supervision to open the learner's critical thinking. The orientation of innovative learning lies on the learner's activity. Therefore, the learning model is expected to adopt the student active approach without decrease the effectiveness of the learning process in class.

In making the students to be active, the willing and the support to be involved in the whole learning process are needed. In this respect, the importance of the motivation's role in learning is displayed. If the students are not motivated, the learning activity is not a success and the results of students' learning are also not satisfying (Ratumanan, 2002). Due to the curriculum 2013 which applies nowadays, the requirement of education has changed a lot. The educator needs to construct and perform the learning and teaching process in which the students can be active in constructing their own knowledge through the process of observing, questioning, experimenting, associating, and finally communicating. Students are expected to interact more with their classmates in constructing their knowledge by implementing the ideas which is based on their experience. One of learning model which can give freedom to the students to be able to interact to one another in groups is the quantum learning model. The quantum model elaborates the new ways to ease the learning process through the blending the art elements and the controlled achievement in any subjects, this model also engages the educator to educate accurately, delightfully, and impressively.

In accordance to that, it is necessary for a teacher accompanied by the learning technology can prepare various type of learning model and media which is oriented on the use of information and communication technology. Various media technology can be used, and one of them is the learning video. Another function of the learning video is that the learning video is able to attract the students' interest and attention, clarify and illustrate the idea so that the students will not easily forget. Beside that, economically the video is considered as an affordable media and operation so it is easy to be applied in the region where the teachers and the students are still low in the information and communication technology literacy. The use of video can drag the students out in learning. Students will respond from what they hear and see, so that the message of the content of the material in the video will be constructed by the students' brain and create a feedback in form of questions about the material which will create the interaction between the students and the educator.

Many factors could affect the learners' result of learning. The internal factors are like the motivation, interest, and the style of learning, and also the external environment like the teacher's and parents' role which take an effect in learning. The curriculum 2013 has a specific purpose for the Physical Education; beside of creating the healthy physic, it is also to strengthen the mental. To actualize the learning purpose, the active learning which involves students' senses is needed to improve students' curiosity and give the learning experience to the students. The improvement of the curiosity will take an effect on the improvement of the students' result on learning especially in the psychomotor/skill sense. The problem of the study in this paper is to investigate which design of the quantum learning with video assisted is appropriate to improve the psychomotor result in learning? 


\section{Method}

This paper is arranged based on the library analysis, journal searching, and empirical proofs from relevant study.

\section{Findings and Discussion}

\section{Design of Quantum Learning to Improve Psychomotor Result in Learning}

Quantum Teaching is a type of learning which blends the art elements and controlled achievement in any subjects. DePorter, et al (2011:37) states that "Quantum Teaching is a model which is like a symphony, there are many elements which can be the musical experience in which the elements are divided into two categories, and they are: context and content". Philosophically Quantum Teaching has three keywords, they are: 1) Quantum is an interaction which converts an energy to light, QT therefore is the conversion many kinds of interaction inside and around the learning moment where these interactions convert the students' skill and ability to be the light which can be useful for themselves and others; 2) Learning acceleration, removing the obstacles which prevent the natural learning process by using music, coloring the environment around the students, arranging the appropriate learning material, the effective presentation and active involvement all on purpose; 3) Facilitation which eases everything.

Quantum Teaching according to DePorter, et al (2011:32) is a conversion of delightful learning, with the entire atmosphere containing any kinds of interaction and differences which maximize the learning moment. Based on those opinions from the experts, it can be concluded that the Quantum teaching model is a learning which can create the effective learning environment, ease the learning process, delightful, spirit pushing and fun in all of the elements (context and content) which is oriented on the students' nature potential.

This learning concept blends every strategy, method, and learning model which according to DePorter, et al (2011:34) is based on the principle "Bring Their World to Ours, and Take Our World to Theirs". This principle guides the educators of the importance to enter the students' world as the first step. To get the right to teach, an educator should build the authentic bridge to enter the students' world.

This action will give an access to the educator to lead, guide, and ease their path to the awareness and wider knowledge. It can be done by relating what the educator have taught with an event, thought, or feeling which is inquired from their home, social, athletic, musical, art, recreation, and academic life. Explicitly, Andi (2009: 119) states that "Children are not you, do not communicate with children using adult's frame, understand their world first, then their world for us".

After the relation is created, the educator may bring them to the educator's world and give them the understanding of the content of the world. Here, the new terms, mental model, formula, and everything else are explained. While exploring the relation and the interaction, both students and educator get the new understanding and "Our World" are broaden not only for students but teacher as well. Finally by the deeper understanding and mastery students are able to bring what they have learned into their world and implement it to the new situation.

\section{The Principles of Quantum Teaching}

Quantum teaching has five principles. Those principles can be explained as follows:

1) Everything talks

Every thing from the classroom environment to the educator's body language, from paper to the learning arrangement send a message about learning.

2) Everything is on purpose Everything happened in the change of educator has a purpose

3) Experience before giving a name

Our brain develops fast by the complex stimulus which move the curiosity, therefore the best learning process is when the students has experience the information before they get a name for what have they learned.

4) Admit every effort

Learning has its own risk, which means stepping out from the comfort zone, therefore, students deserve to be appreciated for the ability and the confidence.

5) If it is worth to be learned, it is worth to be celebrated.

Celebration is the breakfast for the champion students. Celebration gives feedback about the improvement and increase the association of positive emotion by learning.

\section{Practicing the Quantum Teaching}

Quantum Teaching is divided into two main parts; they are the context and the content. The context which is meant here contains: the supporting atmosphere, strong basic, supporting environment and dynamic learning arrangement. Meanwhile, content is related with the skill of delivering for any kind of curriculum, it 
consist of: fine presentation, good facilities, learning skill to learn and life skill. To practice the Quantum Teaching which is related with the context and the content will be explained as follows.

\section{Orchestrating the success through the context (arranging the stage)}

In the change of every detail, the educators prepare context where the students learn positively, support, and raise the appetite. The place to raise the awareness, hearing sense, participation, feedback, and growth is appreciated. The environment where the students are in good condition and willing to take a responsibility and trust each other, which is said to be the classroom can be the "house" where the students learn to appreciate and support one another, place where they experience happiness and satisfaction, giving and accepting, learning, and growing.

1) Atmosphere, the delightful atmosphere can bring joy in learning.

2) Basic, the framework consists of the purpose, belief, policy agreement, procedure, and rules which gives the students and educator a guidance to learn in learning community.

3) Environment, every thing which support the learning process including the way of the educator to arrange the class' stage, such as: lighting, color, table and chair arrangement, plant, music, and so on.

4) Planning, the creation is controlled by the important elements which can rise the students' interest for deeper meaning and fix the information exchange process.

\section{Orchestrating the stimulating atmosphere}

Research shows that the social environment or classroom atmosphere is the main psychology determinant which affects the academic learning (Walberg \& Greeberg in DePorter, 2011: 49). The key materials to build up the good atmosphere are the willing, relationship, joy and impression, risk taking, sense of belongings and good example.

1) The inner strength of a will

The strong will of an educator or the trust on the students' ability and motivation should be clear. Trust that the students are doing their best, they can success, and will success. The key is to get rid of all threats, involve the students' emotion and build relationship.

2) Build the sympathy and understanding

To attract the students' attention, the educators should build up relationship by build the sympathy and understanding. The relationship will build the bridge to the students' fascinating life, open the way to their new world, know their interest and all their greatest success, and speak their heart language. Developing the relationship can ease the educator to involve the students, manage the class, and raising the joy.

3) Joyfulness and Impression

Create the chance to bring happiness so that the learning activity will be more fun. The joy makes the students are ready to study and it can even change the negative attitude. There are three ways how to insert joy in the learning they are affirmation, appreciation, and celebration.

4) Risk taking

Learning contains some risks. Every time we are on adventure to learn something new, we take a big risk out of our comfort zone.

5) Sense of Belongings

Building the sense of belonging will fasten the learning process and increase the students' sense of responsibility. The sense of belongings creates the togetherness, agreement, and support in learning.

6) Good example

Giving the good example is an effective way to build relationship and understanding another person. As the saying goes "The action speaks louder than words, we need prove not a promise, and practice what you preach". All leads to the good example. The more we show the good example, the more they are interested in us and imitate us.

\section{Orchestrating the strong foundation}

A foundation aims to build a context for Quantum Teaching (QT). The educator can create a strong foundation in classroom by creating the clear parameter and guidance to be followed by the students, such as: purpose, principles, beliefs, procedure, policy, rules, and agreement. These parameters should be clear for the students and they have to be committed to follow them. Here, the parameters will be explained, as follows:

1) Purpose

The same purposes for the students are to develop the skill on every subject, be a good learner, and interact to one another, as well as develop another important skill.

2) Principles

These principles are similar with the awareness which will lead the attitude and help the development of the environment which trust and support each other. To make the principles blend with the students, therefore each of the students have to agree that the principles are important and respected by doing three steps to build it up, they are: first, teach these keys by the good example, second, introduce these keys 
through stories and proverbs, third implement these keys into the curriculum. The keys which are meant here are:

(1) Integrity: be honest, sincere, and comprehensive

(2) The failure is the beginning of a success: there is no failure; there is only result and feedback. All of them can be useful if we know how to find the wisdom

(3) Talk in good will: talk with the positive understanding and be responsible for the honest and straight communication

(4) Live in resent: use the time wisely and do every task as good as possible

(5) Commitment: fulfill the promise and obligation

(6) Responsible: Be responsible for every action done

(7) Flexible: be open to a change or new approach

(8) Balance: keep the mind, body, and soul balance

3) Agreement, policy, procedure, and rules

(1) Agreement is more informal than rules and is a conventional and concrete way to smoothen the learning process

(2) Policy supports the purpose of the educator's learning community

(3) Rules are stricter than agreement or policy and to break the rules should cause the clear consequences.

\section{Orchestrating the supporting environment}

Human brain is full with stimulus and brain chooses a certain focus at some moments, for instance when we read unconsciously when we see alphabet letters, place arrangement, and pictures, as well as flower scent, air temperature, etc. Our brain quickly changes for every situation. To make us know more about QT, there are some requirements for the environment to support the students' memory, they are:

1) The environment around

The view around can support the memory. DePorter, et al (2011: 103) states "A picture can be more meaningful than a thousand of words. DaVinci in Buzan (2002: 42) states "Words language is the second language compared to the language of pictures and this language is used to give a name, show or explain all thoughts and creative findings, the main tool of how the creative the language of picture is". If we use the pictures as the model in learning situation, it will stimulate the visual modality and the consciousness.

2) Supporting devices

Supporting device is the tool which represents the idea

3) Seating arrangement

The educator can teach using the seating in which the arrangement is changed to maximize the learning

\section{Orchestrating the dynamic learning plan}

Stimulating the students' satisfying learning process, using the students' intelligence, improving their motivation, and preparing them to reach the success can be done by some ways as follows:

1) Bring their world into ours and take their worlds into ours

The point of QT lies on the ability to bridge the gap between our world and their world. This is meant to ease the educators build the relationship, finish the learning material fast, make the result of learning to be more stick on memory and make sure that there is a transfer of knowledge.

2) The modality of V-A-K

(1) Visual, accessing the visual which can be created or remembered, containing: color, portrait, space, and so on.

(2) Audiovisual, accessing every kind of sound and words which are created or remembered, containing: music, internal dialog, voice, and so on.

(3) Kinesthetic, accessing every move and emotion which is created or remembered, consists of: gesture, emotional reaction, physical comfort, and so on.

3) Model of Success

QT model give us a chance to help the students reach the success anytime. first, when we introduce the learning content, the educator presents it by multisensory (using the model of $\mathrm{V}-\mathrm{A}-\mathrm{K}$ ), the information is cut into several segments, and there are repetitions. Second, make some small groups (work group, team, or pair) for the steady learning. Third, finish it individually (answering questions, homework, test, quiz, and so on).

4) QT planning framework

The QT planning framework or can be called as "DENDeRC" become the basic of this research which will be developed into learning syntax. Furthermore, the study of "DENDeRC" is explained as follows

(1) Develop

Develop the interest by stating "What is the benefit for me" and use the learners' life

(2) Experience

Create and invite general experience which can be understood by all the learners 
(3) Name

Provide the keywords, concept, model, formula and strategy conventionally and provide with the appropriate data when the interest is high

(4) Demonstrate

Give a chance to the learners to "show that they know". Given the chance for them to relate the experience with the new data, so that they will feel it and make it as a personal experience.

(5) Repeat

Show the learner the ways to repeat the material and make sure that "I know that I really know this".

(6) Celebrate

This is for the appreciation for finishing, participating, and achieving knowledge and skill.

5) Double intelligence meet the SLIM-N-BIL

By the works of Howard Gardner, the cognitive psychologist and co-director of Project Zero in Harvard University, the view on understanding the "Intelligence" has a change. In his work, it is stated:

The theory of multiple intelligences, Gardner has now identified eight intelligences: linguistic intelligence, logical-mathematical intelligence, spatial intelligence, musical intelligence, bodily-kinesthetic intelligence, interpersonal intelligence, intrapersonal intelligence, and naturalist intelligence (Veenema Shirley, 2004: 4-6).

SLIM-N-BIL meant here is an abbreviation of eight multiple intelligences as follows:

(1) Spatial-visual: think in visualize

(2) Linguistic-verbal: think and speak words

(3) Interpersonal: think through communication with others

(4) Musical-rhythmic: think in rhyme and melody

(5) Naturalist: think in natural references

(6) Body kinesthetic: Think through body movement

(7) Intrapersonal: think reflectively

(8) Logic-mathematic: Think through reasoning

\section{Successfulness through the content}

Both the context and the content are important. Context is more like what is shown while content contains a short presentation but fascinating, elegant but interesting. The content is related with the good presentation, flexible facility, learning skill to learn and life skill. Each of those parts will be explained below.

\section{Orchestrating good presentation}

The educator' way to communicate really affects the students in accepting the curriculum. Therefore, the educator needs to make a use of the voice, face, body, and words to improve the effectiveness in speaking. There are some things which are need to be considered to make a good presentation:

1) As a Quantum Teacher

A QT should have some characteristics such as: enthusiastic, prestigious, positive, supple, humorous, flexible, open up, sincere, spontaneous, interesting, and interested on the students and believe that students are able to keep their dream.

2) The compatibility of modality

The modality to process stimuli consists of three modalities, they are visual, audio-visual, and kinaesthetic.

3) Four principles for good communication

The four principles which are meant here are: giving the impression, directing the focus, persuasive, and specific.

4) Nonverbal communication

Every message and body language are same and congruent by using eye contact, facial expression, body movement, effective voice tone, then the educator can send a congruent message which strengthen the nonverbal communication.

5) Effective presentation package

There are the times when the educator teaches, they realize that everyone is different. The differences can be categorized into three package, they are the inventor, leader, and director.

6) Tethering

Tethering is an associated response to the stimulus given to attract the students' interest. Tethering consist of personal tethering, location tethering, and oral tethering.

\section{Orchestrating the flexible facility}

Facilitating is the process to ease the degree of participation wanted, so the learning will be stick on its plan and keep the students' interest, so it is better to follow these methods:

1) Remember the principles of K-E-G

(1) Know it

(2) Explain it 
(3) Get it and give feedback

2) The modal of a success from the facilitator's point of view

(1) The introduction of multiple intelligence

(2) The cutting into segments

(3) Frequent repetition

(4) General view

3) Affecting the attitude with action

(1) Body movement

(2) Space (give some minutes of break)

4) Create strategy

(1) Pose a question

(2) Use mind to get the answer

5) Question-Answer learning

Question-Answer learning can use some question such as: what's happening, what have you learned, how to apply.

\section{Orchestrating the learning skill to learn}

There are five skill to stimulate learning, they are: focus, taking note, organization and preparation for test, quick scanning and recalling technique. To apply those five skills, there are some things to be considered, such as:

1) Use the V-A-K learning style

2) Studying in prime condition, new insight of learning, and relax concentration.

3) Organizing the information

Based on the explanation about the Quantum Teaching, it can be generalize that this model is based on the principle "Bring their world into ours, and take our world to theirs", by using the DENDeRC technique which brings new situation in learning because the implementation suits on the brain which works radial, by inserting the eight key to build the students' character to develop the positive emotion in learning so the students can study comfortably and make the classroom to be a house to learn a good work among themselves.

This model can also blend the students' different learning style, or the VAK modality with the different intelligence on each individual or multiple intelligence, where the learning is done by concerning on the context and the content by inserting the art elements which suits on children's world which full of joy and appreciation for every effort.

\section{Video Integration in Quantum Learning Strategy to Improve Psychomotor Learning Result}

In the accordance to improve the fascination in learning, the interesting and motivating media are needed. Video media is integrated into the quantum strategy, to maximize the learning result especially the in psychomotor learning result. According to Riyana (2007), video is a learning media which presents audio and visual which contains some good learning values consists of principles, procedures, and application theory of knowledge to help the understanding of a material. Video is an audio visual media which contains some learning values. It is said to be audio visual because the audio and the visual elements are presented at the same time.

Video is a learning material which is provided through video file and can be seen by using video/VCD player which is connected to a monitor (Sungkono 2003:65). Video learning media can be categorized to audio visual aids (AVA) or the media which can be seen and heard. Usually this media is saved in form of plate or tape. VCD media is the media with the saving and recording system in which the audio-visual signal is recorded to a plastic disc, not to a magnetic tape (Arsyad 2004:36)

According to Riyana (2007: 8-11), to produce a learning video which is able to improve the motivation and effectiveness of the user, the development of the learning video should concern on the characteristic and the criteria. The characteristics of a learnig video are: 1) Clarity of Message. By using the video as media, students are able to understand the message of the learning and the information can be accepted wholly so that the information will be save in the long-term memory. 2) Stand Alone. The video which is developed is not depending on or used together with another learning material. 3) User Friendly. The video media use a simple language and easy to be understood. The information given is helping and friendly with the user, including the easiness for the user to respond and access as the user wants. 4) The representation of the material content should be really representative, for example the material about simulation or demonstration. Basically learning material both in social or science can be made into video. 5) Visualization with the media. The materials are designed with multimedia, containing text, animation, sound, and video which is appropriate with the material. The materials used are applicative, processing, and hard to get, dangerous to be practiced, and has high degree of accuracy. 6) Using high quality of resolution. The display in form of graphic video media is made of digital technology for manipulation with high resolution but supports every computer system. 7) Can be used classically or individually. The video can be used by the students individually not only in school, but also at home. It can be also used 
classically with the number of students 50 at maximum. It can be guided by teacher or only by listen to the narration which is already provided inside the program.

Meanwhile the other characteristics for video media according Riyana (2007:7) are as follows:

1) Television/video is able to enlarge the tiny object which can't be seen.

2) By editing, the object produced can be copied

3) Television/video is also able to manipulate the display, sometimes the object can be manipulated according to the message which will be delivered, for example the object from the past can be combined with the object from the present.

4) Television/video is able to make the object can be saved at some duration still.

5) The attractiveness of television/video can maintain the audience's attention better compare to only listening which only can last for 25-30 minutes.

6) Television/video is able to show the latest and actual pictures and information.

Meanwhile the characteristics of learning video media according to Arsyad (2004: 37-52) are as follows:

1) Can be saved and used many times

2) Have special techniques, for a good arrangement in presenting or saving

3) Easy operation

4) Can present the event from the past or from another place

The video learning material is really important and need to be developed in the learning process in the primary school, considering that the material is able to present audio and visual elements at the same time. Video as a learning media will be able to attract students' attention and motivation in primary school in learning activity. This learning video material will be more interesting for the students because it is able to show the real objects which are far, dangerous, and haven't be seen by the students.

The advantages of the video as learning material are: a) It is a media which mix the visual and audio; b) it is able to affect human's attitude more than printed media; c) can be used immediately; d) can be used repetitively; e) can provide the material which physically cannot be able to be brought into the classroom; f) can present the object on details; g) no need for a darkroom; h) can present a dangerous object; i) can be slowed down or fasten; and j) can be used classically or individually. Beside that the advantage using the video is flexible and can be managed according to the importance. Video is the learning material which is rich of information and direct because it can be shown directly to the students, and video also add new dimension of learning.

\section{References}

Arsyad, Azhar. (2004). Media Pembelajaran. Jakarta: PT. Raja Grafindo Persada.

De Porter, et al. (2005). Quantum Teaching Mempraktikkan Quantum learning di Ruang-ruang Kelas. Bandung: Mizan Pustaka.

Joyce, B., \& Weil, M. (1996). Models of Teaching, $5^{\text {th }}$ Edition. Boston: Allyn and Bacon.

Merrill, M. D., \& Tennyson, R. D. (1977). Teaching Concepts: An Instructional Design Guide. Englewood Cliffs, New Jersey: Educational Technology Publications.

Nichols Baverly. (1994). Moving and Learning the Elementary School Physical Education Experience, Edisi ke3, Mosby-Year Book, Inc.

PASI. (1993). Pedoman Dasar Melatih Atletik. Program Pendidikan dan Sistem Sertifikasi Pelatih Atletik.

Permendikbud No 81 Tahun 2013. (2013). Struktur Kurikulum 2013. Jakarta: Depdikbud

Riyana, Cheppy. (2007). Pedoman Pengembangan Media Video. Jakarta: P3AI UPI.

Sudjana, Nana dan Ahmad Rivai. (2007). Teknologi Pengajaran. Bandung: Sinar Baru Algesindo

Trianto. (2007). Model-Model Pembelajaran Inovatif Berorientasi Konstruktivistik Konsep, Landasan, TeoritisPraktis, dan Implementasinya. Jakarta: Prestasi Pustaka. 